\title{
Sensitivity of feedback effects in CBMZ/MOSAIC chemical mechanism
}

\author{
R. San José ${ }^{\mathrm{a}, ~ *}$, J.L. Pérez ${ }^{\mathrm{a}}$, A. Balzarini ${ }^{\mathrm{b}}$, R. Baró ${ }^{\mathrm{c}}$, G. Curci ${ }^{\mathrm{d}}$, R. Forkel ${ }^{\mathrm{g}}, \mathrm{S}$. Galmarini ${ }^{\mathrm{i}}$, \\ G. Grell ${ }^{\text {h }}$, M. Hirtl ${ }^{\text {e }}$, L. Honzak ${ }^{\text {f }}$ U. Im ${ }^{\text {i }}$, P. Jiménez-Guerrero ${ }^{\text {c }}$, M. Langer ${ }^{\text {e }}$, G. Pirovano ${ }^{\text {b }}$, \\ P. Tuccella ${ }^{\mathrm{d}}$, J. Werhahn ${ }^{\mathrm{g}}$, R. Žabkar ${ }^{\mathrm{j}}$ \\ a Technical Univ. of Madrid, ESMG-UPM, Spain \\ ${ }^{\mathrm{b}}$ RSE, Milano, Italy \\ ${ }^{c}$ University of Murcia, MAR-UMU, Spain \\ 'University L'Aquila, CETEMPS, Italy \\ e ZAMG, Vienna, Austria \\ ${ }^{\mathrm{f}}$ Center of Excellence SPACE-SI, Ljubljana, Slovenia \\ ${ }^{g}$ Karlsruhe Inst. of Technology, IMK-IFU, Garmisch-Partenkirchen, Germany \\ ${ }^{\mathrm{h}}$ Earth System Research Laboratory, Boulder, USA \\ ${ }^{\mathrm{i}}$ EC, JRC, Institute for Environment and Sustainability, IES, Ispra, Italy \\ j University of Ljubljana, Faculty of Mathematics and Physics, Ljubljana, Slovenia and Center of Excellence SPACE-SI, Ljubljana, Slovenia
}

A B S T R A C T

To investigate the impact of the aerosol effects on meteorological variables and pollutant concentrations two simulations with the WRF-Chem model have been performed over Europe for year 2010. We have performed a baseline simulation without any feedback effects and a second simulation including the direct as well as the indirect aerosol effect. The paper describes the full configuration of the model, the simulation design, special impacts and evaluation. Although low aerosol particle concentrations are detected, the inclusion of the feedback effects results in an increase of solar radiation at the surface over cloudy areas (North-West, including the Atlantic) and decrease over more sunny locations (SouthEast). Aerosol effects produce an increase of the water vapor and decrease the planet boundary layer height over the whole domain except in the Sahara area, where the maximum particle concentrations are detected. Significant ozone concentrations are found over the Mediterranean area. Simulated feedback effects between aerosol concentrations and meteorological variables and on pollutant distributions strongly depend on the aerosol concentrations and the clouds. Further investigations are necessary with higher aerosol particle concentrations. WRF-Chem variables are evaluated using available hourly ob-servations in terms of performance statistics. Standardized observations from the ENSEMBLE system webinterface were used. The research was developed under the second phase of Air Quality Model Evaluation International Initiative (AQMEII). WRF-Chem demonstrates its capability in capturing tem-poral and spatial variations of the major meteorological variables and pollutants, except the wind speed over complex terrain. The wind speed bias may affect the accuracy in the chemical predictions $\left(\mathrm{NO}_{2}, \mathrm{SO}_{2}\right)$. The analysis of the correlations between simulated data sets and observational data sets indicates that the simulation with aerosol effects performs slightly better. These results indicate potential importance of the aerosol feedback effects and an urgent need to further improve the representations in current atmospheric models to reduce uncertainties at all scales.

\footnotetext{
* Corresponding author.

E-mail address: roberto@fi.upm.es (R. San José).
} 


\section{Introduction}

Aerosols are known to affect weather and climate via several ways but the feedback effects are one of the most uncertain research areas in air quality and climate modeling (Jacob and Winner, 2009). These uncertainties diminish our capability to generate reliable climate projections and to provide accurate weather and air quality predictions so, research tasks should be addressed to reduce these uncertainties. Aerosols and their precursors have both natural sources resulting from desert dust lifting, sea spray, volcanic eruptions, biogenic organic emissions and anthropogenic sources such as fossil fuel and biomass burning. The aerosols may produce a reduction of downward solar radiation (direct effect), a change in near surface temperature and thermal stability due to absorption of solar radiation which leads subsequently to a change in cloudiness (semi-direct effect) a decrease in cloud drop size but an increase in cloud droplet number concentrations through their role as cloud condensation nuclei (indirect effect). These effects have been observed in the past (Kaufman and Fraser, 1997; Rosenfeld and Woodley, 1999). New studies have been developed to study the multiple interactions between meteorology and chemistry in the atmosphere, for example aerosol-cloudradiation feedback effects (Zhang, 2008; Zhang et al., 2010; Forkel et al., 2012) and interactions between temperature, gas-phase chemistry and aerosols (Baklanov et al., 2014) We can also find opposite effects of the aerosols on the meteorological variables, for example the precipitation. Aerosols can decrease solar radiation on surface, so less heat is available for water evaporation and a reduction of precipitation is observed. On the other hand, depending of the absorbing characteristics of the aerosols (mineral dust, black carbon ...) they could energize convective clouds and thus increasing precipitation (Levin and Brenguier, 2009). Feedback effects can be particularly important during strong particles episodes (Konovalov et al., 2011; Chen et al., 2014; Wong et al., 2012).

Realistic simulation of the feedback effects requires the use of integrated meteorology-chemistry on-line models that include detailed treatment of aerosol life cycle and aerosol impacts on radiation (direct effects) and clouds (indirect effects) (Baklanov et al., 2014; Grell and Baklanov, 2011, Bangert et al., 2012; Yang et al., 2011). Historically, the study of these effects has been done separately in modeling approaches. Chemistry and weather forecasts have been developed as separate disciplines, leading to the creation of separate modeling systems that are only loosely coupled (offline) (Grell and Baklanov, 2011). Fully coupled on-line models, where meteorological and chemical processes are solved together on the same grid and with the same physical parameterizations are able to simulate the complex aerosol-cloud-radiation feedback effects (Zhang, 2008). Recent case studies have shown that the inclusion of feedback effects can improve the model performance for specific cases and conditions (Grell et al., 2011; Bangert et al., 2012; Yang et al., 2011; Forkel et al., 2012). More research and studies are needed to investigate how the inclusion of feedback effects within on-line air quality models affects the simulation results over Europe for a longer simulation episode.

The Weather Research and Forecasting (WRF) model is a mesoscale non-hydrostatic meteorological model. WRF-Chem is a version of WRF coupled on-line with a chemistry model where meteorological and chemical components of the model are predicted simultaneously (Grell et al., 2005). WRF-Chem is used for the simulations because it represents a state of the art in air quality online modeling.

The simulations have been run under the umbrella of the second phase of the AQMEII (Air Quality Model Evaluation International Initiative; http://aqmeii.jrc.ec.europa.eu/) model inter-comparison exercise, led by the Joint Research Center of the EU and the United States Environmental Protection Agency (US EPA). The simulations will contribute to the general objectives: (1) to exchange expert knowledge in regional air quality-climate modeling; (2) to identify gaps in the knowledge of air quality-climate science; (3) to develop methodologies to evaluate uncertainty in aerosol-climate interactions; (4) to establish methodologies for model evaluation to enhance the knowledge on climate processes and; (5) to support the use of models for inter-comparison exercises.

The evaluation of the model results through comparison with measurement and the analysis of the variables related to the climate-chemistry-aerosol-cloud-radiation feedback effects have been developed using the ENSEMBLE system (Bianconi et al., 2004; Galmarini et al., 2012). It is a web-based platform for model intercomparison and multi-model ensemble analysis that has been in use since 2000 for emergency response application at the Joint Research Center in Ispra (Italy). The ENSEMBLE system acts as the central hub for modeling information and will provide on-line graphical representation tools to all data providers and access to all of the available model and monitoring data. The choice of a common analysis platform in this context helps guarantee the maximum level of harmonization among the various datasets and therefore of inter-comparability and evaluation.

\section{Experiment setup}

In order to investigate the impact of aerosol feedback effects, two WRF-Chem simulations are compared. The two simulations differ by the aerosol-meteorology interactions that were considered. The first simulation (baseline, NONFBIT1) is not taking into account any interactions between simulated aerosol concentrations and meteorology, i.e. solar radiation is not affected by the simulated aerosol concentrations and also simulated cloud droplet numbers and radiative properties do not depend on the simulated aerosol numbers. The second simulation (FBES3) differs from the baseline simulation by the inclusion of these effects (direct and indirect aerosol effect). This simulation also includes some aqueous phase chemical reactions within the cloud droplets.

With exception of the inclusion or omission of the aerosol radiative effect and the effect of simulated aerosol concentration on cloud properties WRF-Chem version 3.4 .1 is configured identically for both simulations with the following common options: the Yonsei University (YSU) PBL scheme (Hong et al., 2006), the NOAH land-surface model (Chen and Dudhia, 2001), the Morrison doublemoment cloud microphysics scheme (Morrison et al., 2009) and the Grell-3D cumulus parameterization that is an updated version of the Grell-Devenyi scheme (Grell and Devenyi, 2002) with radiative feedback and shallow convection. The Rapid Radiative Transfer Method for Global (RRTMG) long-wave and short-wave radiation scheme (lacono et al., 2008) is applied for both simulations. 
Simulation FBES3 accounts for the effect of simulated aerosol concentrations on radiation. The direct effect of aerosols on shortwave radiation in FBES3 is simulated based on Mie theory following the approach of Fast et al. (2006). However, no extinction due to aerosol particles is taken into account for simulation NONFBIT1, i.e. although aerosol is also simulated for the case NONFBIT1, no aerosol is assumed within the radiation modules.

The gas-phase chemistry is based on the Carbon-Bond Mechanism version Z (CBM-Z, Zaveri and Peters, 1999) mechanism. It has 67 species and 164 reactions in a lumped structure approach that classifies organic compounds according to their internal bond types. Rates for photolytic reactions are derived using the Fast-J photolysis rate scheme (Wild et al., 2000). The aerosol module is the Model for Simulating Aerosol Interactions and Chemistry (MOSAIC) (Zaveri et al., 2008). MOSAIC includes sulfate, methanesulfonate, nitrate, chloride, carbonate, ammonium, sodium, calcium, black carbon (BC), primary organic mass (OC), liquid water, and other inorganic mass (OIN) with 4 Bin size ranges: (1) $3 \mathrm{~nm}-$ $156 \mathrm{~nm}$; (2) $156 \mathrm{~nm}-625 \mathrm{~nm}$; (3) $625 \mathrm{~nm}-2.5 \mu \mathrm{m}$; (4) $2.5 \mu \mathrm{m}-$ $10 \mu \mathrm{m}$. Secondary organic aerosol formation is not considered. MOSAIC simulates major aerosol processes (e.g., inorganic aerosol thermodynamic equilibrium, binary nucleation, coagulation, condensation. A new dust flux constant and a desert dust improvement for spurious fluxes was introduced for the baseline simulation.

As simulation FBES3 accounts explicitly for aerosol cloud interactions on the basis of simulated aerosol concentrations and the indirect aerosol effect on radiation. In addition, formation of sulfate due to aqueous-phase chemistry is included in the FBES3 simulation. Condensation as well as aerosol scavenging by cloud droplet and wet deposition depend on simulated aerosol concentrations. The indirect effect of aerosols on cloud formation is accounted for the effects of clouds on shortwave radiation, treatments of aerosol activation/resuspension, and prognostic CDNC based on activated aerosols, as described by Chapman et al. (2009). However, simulated aerosol concentrations are only considered for aerosol cloud interactions and the indirect effect for the grid scale clouds. Since subgrid clouds contribute to considerable amount to total precipitation the effect of explicit consideration of aerosol cloud interactions found here may be considered as a lower limit for the effect.

Since the 'no aerosol' assumption which is applied in NONFBIT1 for the radiation calculation is not possible with respect to aerosol cloud interactions (this would mean the unrealistic case of homogeneous nucleation) some assumption must be made if aerosol cloud interactions do not depend explicitly on simulated aerosol mass and numbers. The baseline assumption for the WRF/WRFChem in this case is continental aerosol throughout the entire domain.

The current simulations are part of the second phase of the AQMEII (Air Quality Model Evaluation International Initiative; http://aqmeii.jrc.ec.europa.eu/) model inter-comparison exercise (Im et al., 2014a, 2014b) and complement further five WRF-Chem simulations for Europe within this exercise, where a modal aerosol description was applied (Forkel et al., 2014; Baró et al., 2014). According to the common simulation strategy for AQMEII phase 2, the whole year 2010 was simulated as a sequence of 2-day time slices. The chemical state of the model is restarted from previous run, while meteorology is reinitialized each time-slot. It is clear that the simulation results will depend to some extent on the choice of length of the time slices (Wolke et al., 2012). Two days were considered by the organizers of AQMEII phase 2 as a compromise between allowing for direct and indirect aerosol effects on the one side and keeping the decline of the forecast quality and the unconstrained propagation of feedback effects, e.g. the disturbance of cloud cover due to changed energy balance etc. within limits. The first five days of simulation (26-31 December, 2009) are used as chemistry spin-up period. Nudging techniques have not been applied because they can suppress most feedback effects. The differences in model predictions between the two simulations for meteorological variables and air quality concentrations provide an estimate of the aerosol feedback effects.

The big modeling domain covers Europe and a portion of $s$ northern Africa and as well as large areas affected by the Russian forest fires in 2010, with 270 by 225 grid cells projected at Lambert Conformal Conic (LCC) projection centered in latitude $50 \mathrm{~N}$, and longitude $12 \mathrm{E}$. For better comparability, the same grid spacing of $23 \mathrm{~km}$ was adopted. The vertical resolution includes 33 layers from the surface to a fixed pressure of $50 \mathrm{hPa}$ (about $20 \mathrm{~km}$ ) with a finer resolution close to the surface and lowest layer height ca. $24 \mathrm{~m}$. According to the computational resources and CPU time limitations, all WRF-Chem groups of the AQMEII phase2 agreed to run the simulation with 33 layers although we are cognizant that the vertical aerosol distribution can modify the aerosol radiative forcing because scattering particles exhibit a greater forcing when they are located in the lowest levels (Haywood et al., 1999). Shared common processing of initial and boundary conditions data, as well as anthropogenic and fire emissions data have been used.

To obtain the meteorological initial- and boundary conditions for the WRF-Chem runs data from the ECMWF operational archive was used. 3-hourly data (analysis at 00 and 12 UTC and respective forecasts $3 / 6 / 9 \mathrm{~h}$ ) of different fields (e.g. temperature, wind, humidity, surface pressure, soil moisture, ground layer temperature ...) were extracted from the MARS archive. The spatial resolution of the used ECMWF data is $0.25^{\circ}$ and it is provided on 91 model-levels. The data is further processed by the WRF-Chem preprocessor programs which interpolate the fields to the respective grid and provide files containing initial and boundary conditions for the WRF-Chem runs.

The chemical boundary conditions were provided by ECMWF IFS-MOZART model within the MACC-II project (Monitoring Atmospheric Composition and Climate - Interim Implementation; http://www.gmes-atmosphere.eu) every $3 \mathrm{~h}$ with 1.125 degrees of grid resolution. VOC and aerosol mapping from MOZART to CBM-Z and MOSAIC was based on Emmons et al. (2010). Mineral dust aerosol discretization into the MOSAIC four-bin followed Johnson and Osborne (2011).

The anthropogenic emissions are taken from MACC-TNO inventory (Kuenen et al., 2009). MACC-TNO database is a gridded European high resolution inventory $\left(0.125^{\circ} \times 0.0625^{\circ}\right)$ that provides the total annual emissions of $\mathrm{CH}_{4}, \mathrm{NO}_{\mathrm{x}}, \mathrm{CO}, \mathrm{SO}_{2}, \mathrm{NH}_{3}$, NMVOC, unspeciated $\mathrm{PM}_{25}$ and $\mathrm{PM}_{10}$. The horizontal and vertical distribution of the emissions on the model grids, their time variability (monthly, daily and hourly) and NMVOCs speciation is done following Tuccella et al. (2012). The EC and OC emissions are calculated from $\mathrm{PM}_{25}$ by using the method proposed by Builtjes (2003). The conversion factor used to convert the emissions of oC to OM is 1.6 (Bessagnet et al., 2008).

Biomass burning emission data have been calculated from global fire emission data that have been obtained by re-analysis of fire radiative power data obtained by MODIS instrument onboard of Aqua and Terra satellites during an integrated monitoring and modeling system for wildland fires (IS4FIRES) project (Sofiev et al., 2009). The emission data are available for Europe (daily, $0.1 \times 0.1^{\circ}$ spatial resolution) in Netcdf format. Day and night vertical injection profiles (monthly $1.0 \times 1.0^{\circ}$ spatial resolution) is also available with 20 layers from $250 \mathrm{~m}$ to $9750 \mathrm{~m}$, which have been transformed to WRF-Chem vertical layers. The data has been regrided to the WRFChem Lambert Conformal Conic grid using next neighbor interpolation. Fire emission data is given as total particulate matter (TPM). 
WRF-Chem emission species have been calculated by speciation following Andreae and Merlet (2001) and Wiedinmyer et al. (2011).

Biogenic emissions are based on the Model of Emissions of Gases and Aerosols from Nature (MEGAN) model (Guenther et al., 2006). MEGAN is on-line couple with WRF-Chem model and meteorology data from WRF-Chem is used on-line into MEGAN model.

Meteorology and concentrations are analysed using yearly mean spatial distributions. Finally simulated concentrations and meteorological variables were compared against available observations in the domain. Observations include hourly data collected from AirBase and EMEP database. AirBase is the European air quality database maintained by the European Environmental Agency (EEA) through its European topic center on Air pollution and Climate Change mitigation. The European Monitoring and Evaluation Programme (EMEP) is a scientifically-based and policy-driven program under the Convention on Long-range Transboundary Air Pollution (CLRTAP) for international co-operation to solve air pollution problems arising from the transboundary chemical transport of atmospheric contaminants. It comprises more than 100 stations which include aerosol information over Europe.

\section{Results and discussion}

The results from the simulations are presented as two groups. First one is the spatial distribution of the feedback effects impacts and the second one describes the evaluation of the two simulations.

Fig. 1 shows the yearly mean shortwave radiation for base case (NONFBTI1) and absolute differences (FBES3-NONFBIT1) between the feedback effects simulation FBES3 and the base case. The simulation FBES3 which in includes the direct aerosol effect and the impact of simulated aerosol concentrations on cloud droplet formation (and thus the indirect aerosol effect) shows higher values of solar radiation over Atlantic Ocean and North Sea. The yearly mean short wave radiation is up to $70 \%\left(40 \mathrm{~W} / \mathrm{m}^{2}\right)$ higher for FBES3 than for the non-feedback effects simulation. This strong impact is found for the areas of the domain with lowest solar radiation where cloud cover is an important factor. Absorption of solar radiation by black carbon (BC) and other aerosols can reduce cloud formation ("semi- direct effect"). However, due to very low aerosol concentrations over the North Atlantic this effect cannot be responsible for the simulated lower cloud water content and higher solar radiation in the feedback case. Low aerosol concentrations with approximately 300 particles $\mathrm{cm}^{-3}$ (yearly average) are found for this region. When aerosol cloud interactions depend on simulated aerosol concentrations, as in simulation FBES3, these small particle number concentrations result in cloud droplet numbers around $30 \mathrm{~cm}^{-3}$ for the North Atlantic area. This droplet number concentration is much lower than the droplet number concentrations that are assumed for the baseline case NONFBIT1., There, a value of 250 cloud droplets $\mathrm{cm}^{-3}$ is used throughout the modeling domain, which is the assumed default value when no feedback effects of simulated aerosol concentrations on cloud condensation is considered.

The very low cloud droplet numbers for FBES3 result in an earlier onset of precipitation than for the baseline case. We have observed a significant reduction (close to $70 \%$ ) of the cloud liquid water path over the North Atlantic area when feedback effects are activated, values of $196 \mathrm{~g} / \mathrm{m}^{2}$ are observed on NONFBIT1 (base) and only $60 \mathrm{~g} / \mathrm{m}^{2}$ on FBES3 (feedback effects case). Also we found similar values of cloud fraction, $93 \%$ in case of NONFBIT and $90 \%$ for FBES3. This strong decrease of the cloud liquid water content and the associated increase in global radiation can be observed for WRF-Chem not only for the MOSAIC aerosol module but also when the MADE/SORGAM aerosol module (Forkel et al., 2015, Kong et al., 2015) as it results mainly from the definition of the baseline conditions.

Reduction of incoming solar radiation via backscattering occurs over the southern part of the domain where shortwave radiation is reduced up to $30 \mathrm{~W} / \mathrm{m}^{2}(10 \%)$. This reduction is due to the direct aerosol effect by Saharan dust. This effect may probably be underestimated due to the lack of the coarse dust fraction in the FBES3 simulation. The base simulation NONFBIT1 considers also the coarse dust fraction because a new dust fluxes constant and a desert dust improvement for spurious fluxes was introduced in the baseline simulation. However, since the simulated aerosol concentrations are not considered for the calculation of radiative transfer and cloud condensation of the baseline simulation, this addition of coarse dust in NOFBIT1 has no impact on the further

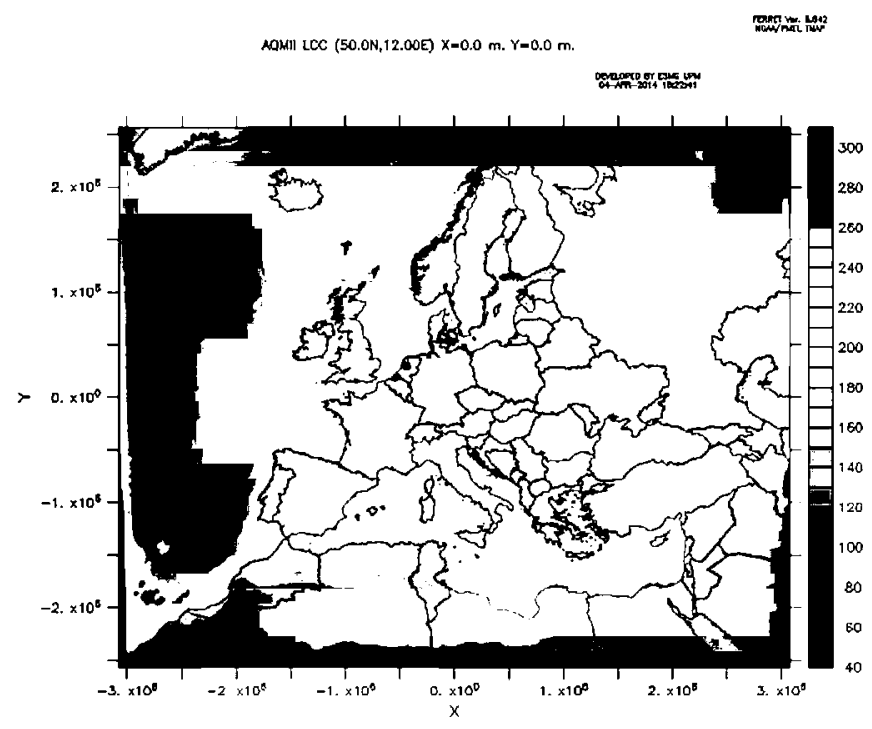

SWDNB $W / m 2$ NONFB.IT1 2010 AVG

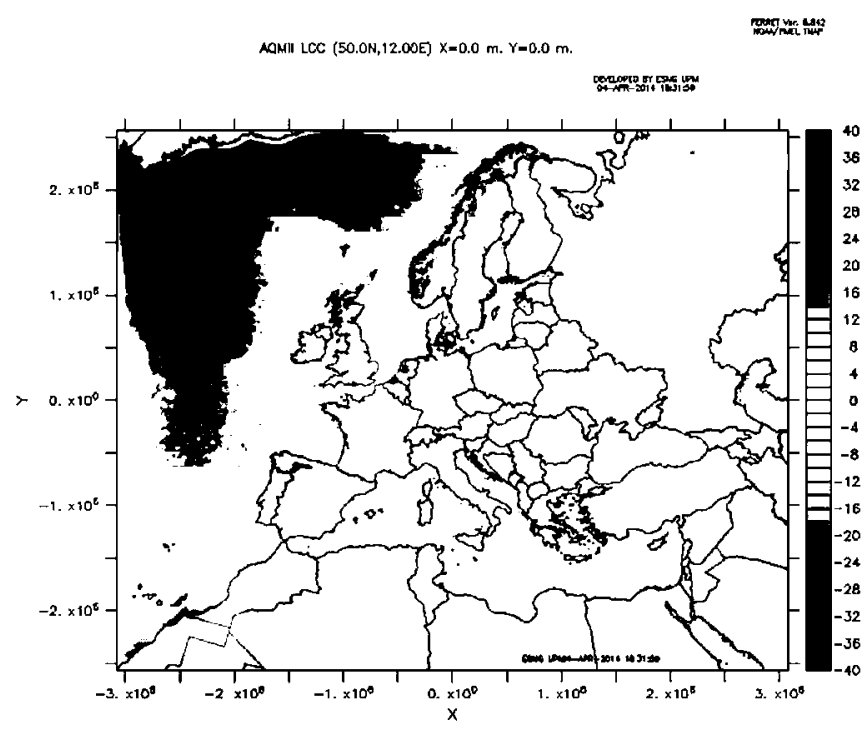

SWDNB $W / m 2$ FBES3 NONFBIT 12010 AVG

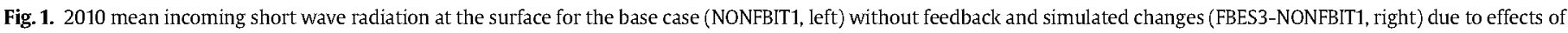
aerosols. 
discussion. When aerosol cloud interactions are explicitly considered, high aerosol particle numbers can result in high cloud numbers and an increased cloud optical depth. Over the Saharan increase of cloud optical depth due to high aerosol particle numbers plays only a minor role in this area due to the absence of clouds.

Fig. 2 shows the yearly mean non-convective rain $(\mathrm{mm})$ for base case (NONFBTI1) and absolute differences (FBES3-NONFBIT1) between the simulated grid scale precipitation for the feedback effects simulation and the base case. Aerosol cloud interactions are not included for convective precipitation.

Precipitation over the Atlantic is increased up to $25 \%$ when the effect of the aerosol on the cloud droplet formation is considered. For this area the FBES3 simulation shows lower values of cloud liquid water path and aerosol concentrations than the NONFBIT1 simulation (base). This enhanced precipitation may explain the temperature decease over North Atlantic that is shown in Fig. 3. . The fact that the microphysics scheme is double moment when running with chemistry and one moment otherwise induces to the indirect effect to be the cause of lower temperatures.

Fig. 4 shows the monthly mean relative differences (FBES3NONFBIT1) of short wave radiation, temperature, and precipitation over North Atlantic Ocean between the feedbacks simulation and the base case. Over this area the increase of the solar radiation and precipitation are higher during the summer. In case of the near surface temperature we found a decrease for all months except May. The differences on precipitation are more important in June with a pronounced cooling effect in spite of the strong increase of the short wave radiation due to the indirect aerosol effect.

Fig. 5 shows the yearly mean water vapor for the base case (NONFBTI1) and relative differences (FBES3-NONFBIT1/NONFBIT1) between the feedback effects simulation and the base case. The inclusion of the direct and indirect aerosol effect resulted in increased water vapor in particular over the North Atlantic and Northern Europe.

Accounting for aerosol radiative effects and aerosol cloud interactions tends to decrease in near surface temperature by up to $0.75 \mathrm{~K}$ over some part of the land areas Also aerosols increase water vapor over most of the domain by up to $3.2 \%$. Over the North Atlantic region, lower particle numbers plus more precipitation result in an increase of water vapor and decreases of temperature for the case FBES3.

Over Northern Scandinavia there is a decrease of the yearly mean temperature due to increased long-wave radiation escaping to space resulting from the decrease of the cloud liquid water path This cooling effect is prevalent in winter and it is dominant in Northern Europe due to the extremely low solar radiation. Some areas with higher particulate concentrations show a decrease in humidity and an increase of the air temperature near surface which follows to some extent the patterns of the change in solar radiation. Since the direct aerosol effect does generally lead to lower solar radiation and near surface temperatures over land surfaces, it can be concluded that the simulated temperature increase is probably due to indirect aerosol effects. There is a special zone at the Eastern part of Northern Africa where warming is observed. This area is close to the sea and not enough dust is emitted by the dust model, so it is an area with lower droplets numbers, increase of short wave radiation but there is no precipitation. Therefore, humidity is decreased and temperature increased.

Fig. 6 shows the yearly mean planetary boundary layer height (PBLH) for base case (NONFBTI1) and absolute differences (FBES3NONFBIT1) between the feedback effects simulation and the base case. The simulations with and without direct and indirect aerosol effect indicate that aerosols lead to reduced mean planetary boundary layer heights over most of the domain by up to $65 \mathrm{~m}$ $(-19 \%)$ except for some areas in Norway and the Western Sahara where PBLH increases up to $40 \%$. This effect could be explained with the feedback effects which enhance the convective process in higher layers close to the BL top.

Fig. 7 shows a vertical profile at one point over the North Atlantic Ocean (NA) of the differences (FBES3-NONFBIT1) for water vapor and temperature. The point is the same that in Fig. 4. The cooling effect over the NA by enhanced precipitation and humidity is present for the lowest layers, above the boundary layer the effect is opposite (increase temperature and decrease water vapor); above $6000 \mathrm{~m}$ the differences are insignificant.

Fig. 8 shows that yearly mean ozone concentrations over Mediterranean area were increased up to $2 \mu \mathrm{g} / \mathrm{m}^{3}$ (3\%) and decreased up to $2.2 \mu \mathrm{g} / \mathrm{m}^{3}$ (3.8\%) over the North Atlantic Ocean for the case FBES3. The differences are associated with changes in solar
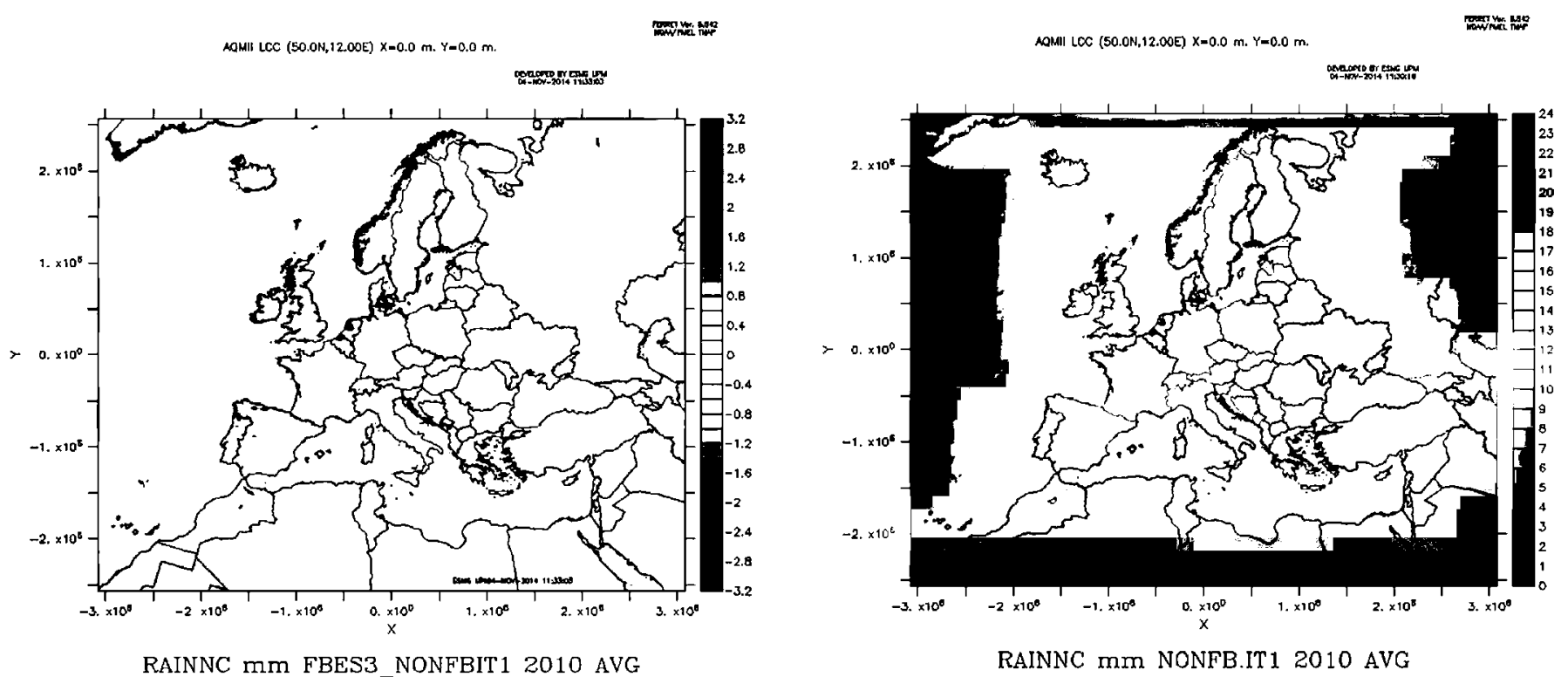

RAINNC mm NONFB.IT1 2010 AVG

Fig. 2. 2010 mean non-convective rain for the base case (NONFBIT1, left) without feedback and simulated changes (FBES3-NONFBIT1, right) due to effects of aerosols. 


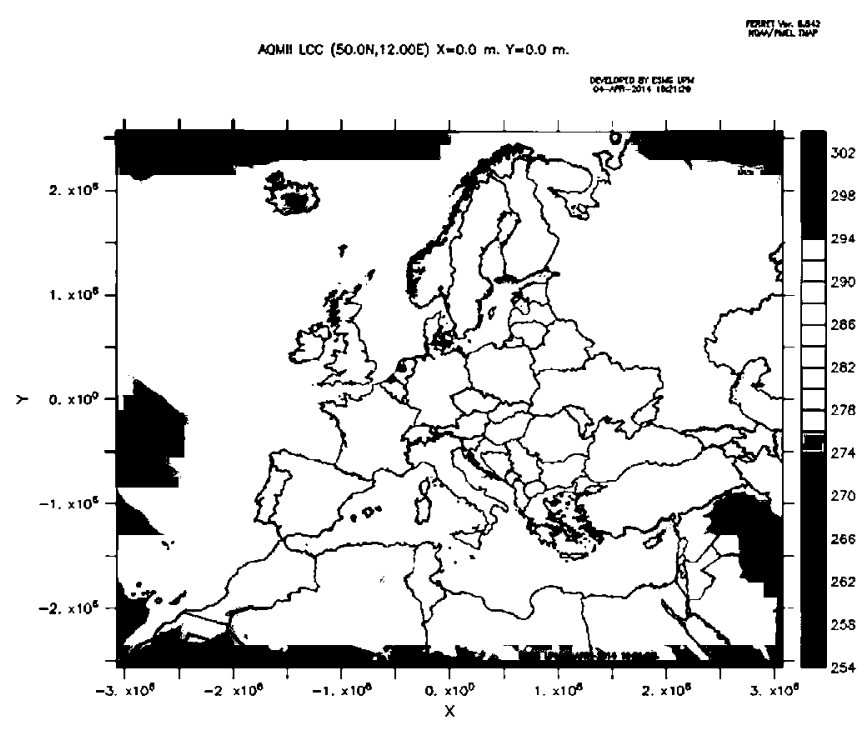

T2 K NONFB.IT1 2010 AVG

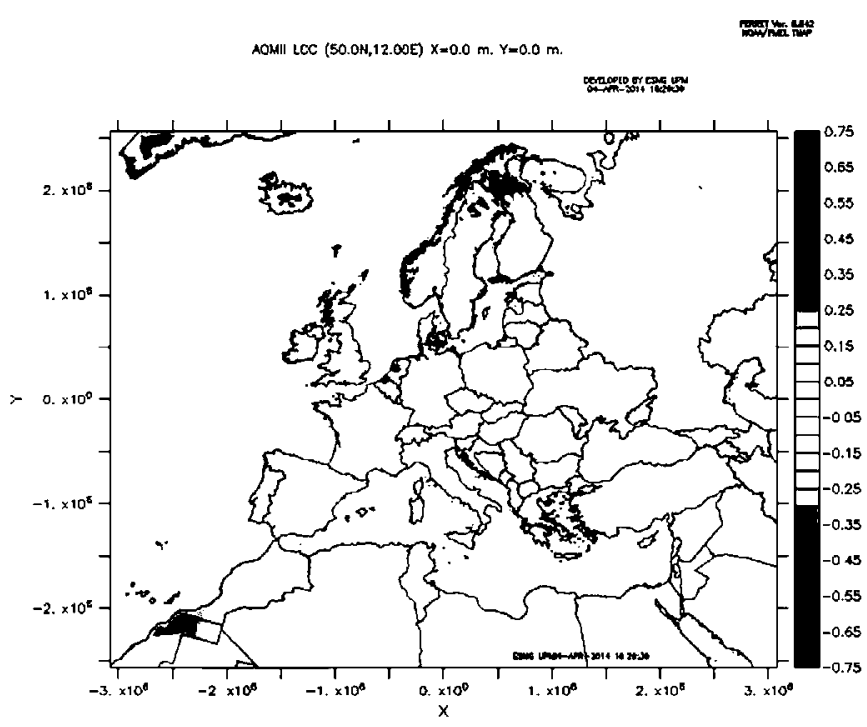

T2 K FBES3_NONFBIT1 2010 AVG

Fig. 3. 2010 mean two meter temperature for the base case (NONFBIT1, left) without feedback and simulated changes (FBES3-NONFBIT1, right) due to effects of aerosols.

Montly differences (FBES3-NONFBIT1) Temperarute (NA point)

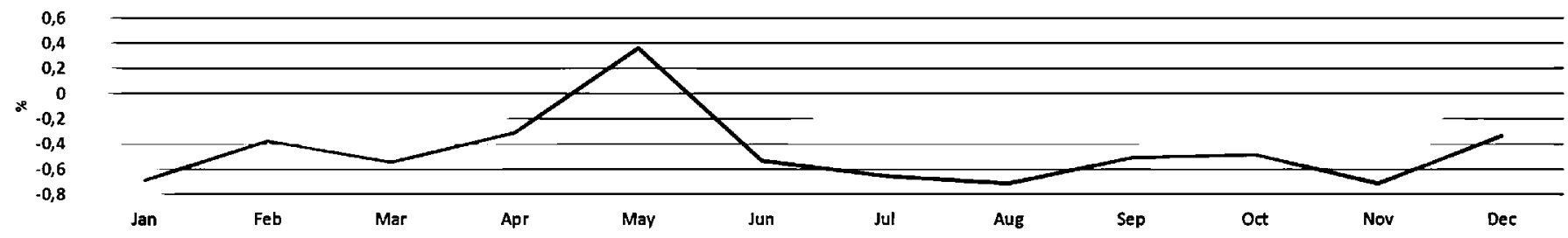

Montly differences (FBES3-NONFBIT1) Short wave radiation (NA point)

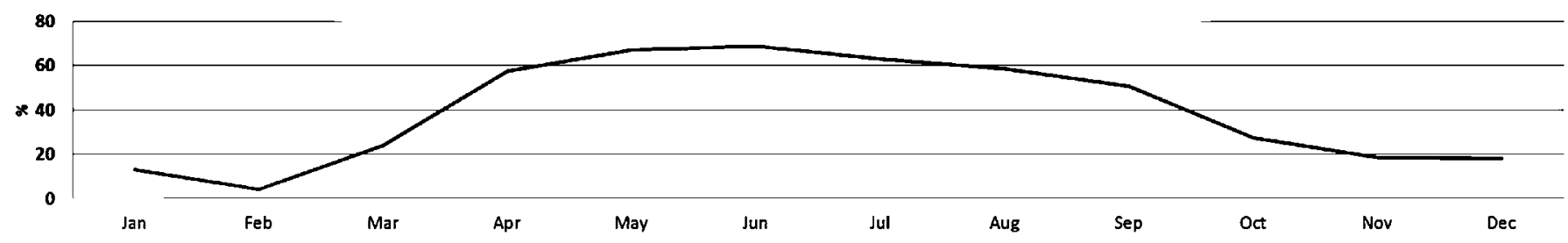

Montly differences (FBES3-NONFBIT1) Precipitation (NA point)

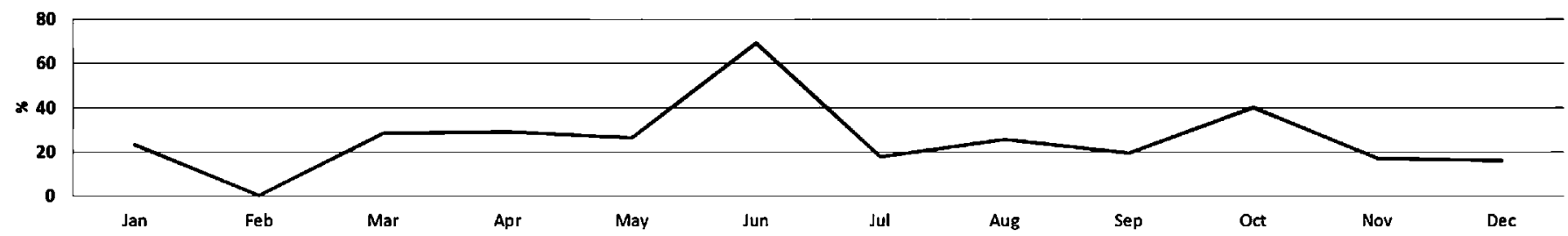

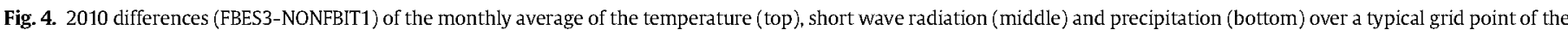
North Atlantic Ocean $(14.5 \mathrm{~W}, 59.0 \mathrm{~N})$.

radiation, water vapor mixing ratio and temperature, and precursor concentrations. Increases of ozone are located over the Mediterranean area where high $\mathrm{NO}_{\mathrm{x}}$ concentrations are observed, and where there is a small increase in the Western and a reduction in solar radiation in the Eastern part but a strong increase of the water vapor mixing ratio; this enhances ozone formation in which overcompensates the effect of the small reduction of the short wave radiation. Over the Atlantic where there are lower ozone concentrations for the case FBES3 in spite of the enhanced solar radiation due to the reduction in surface temperature (Fig. 3).

Yearly mean sulfate particles changes, Fig. 9 , are between $+90 \%$ over central Europe and -90\% over North Atlantic. The differences of the FBES3 with respect to the NONFBIT1 could be explained with the fact that NONFBIT1 does not include the aqueous phase oxidation of $\mathrm{SO}_{2}$ by hydrogen peroxide, which is one of the major sources of sulfate in clouds and precipitation on the regional scale. 


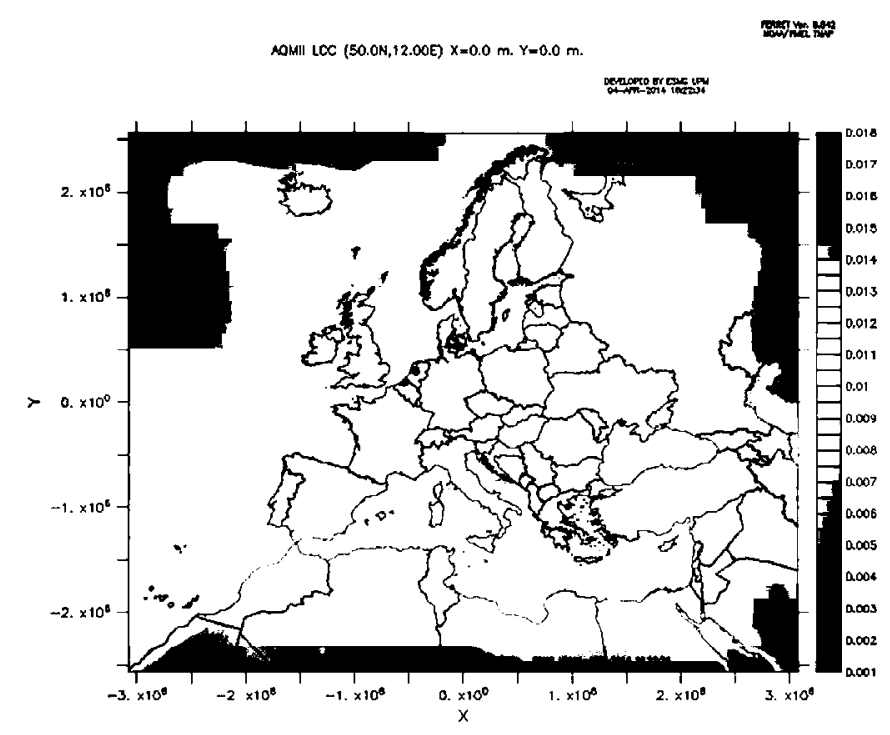

QVAPOR $\mathrm{kg} / \mathrm{kg}$ NONFB.IT1 2010 AVG

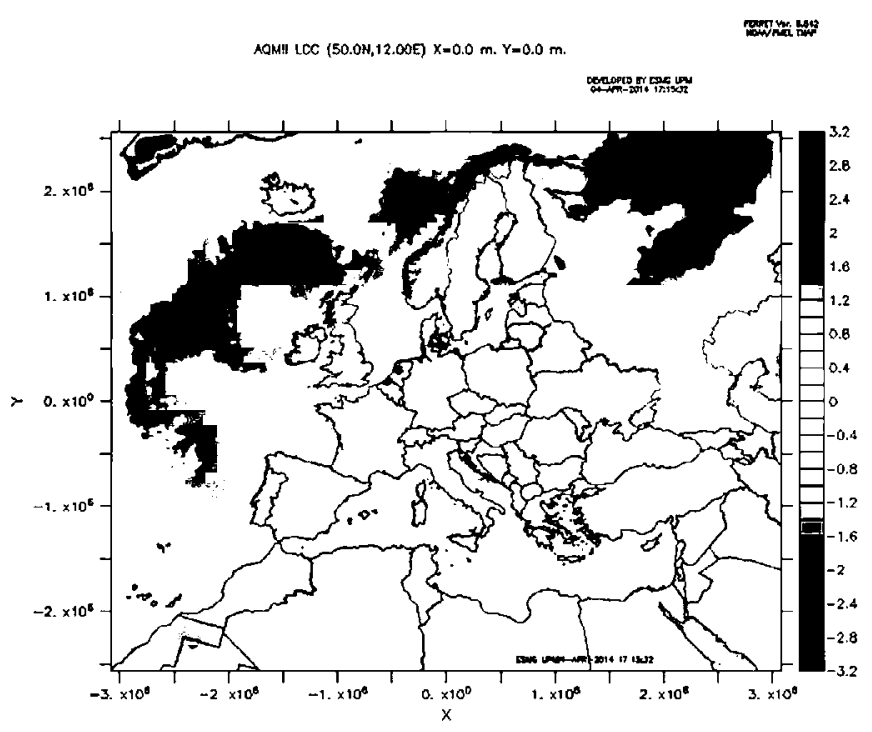

QVAPOR \% FBES3_NONFBIT1 2010 AVG

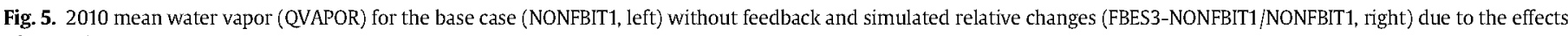
of aerosols.

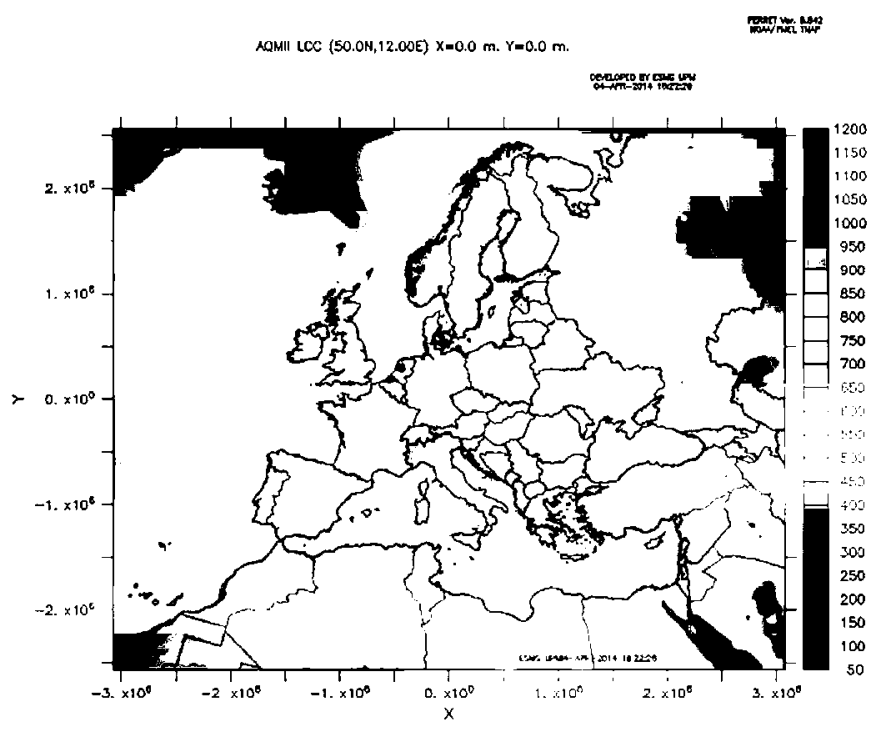

PBLH in NONFB.IT1 2010 AVG

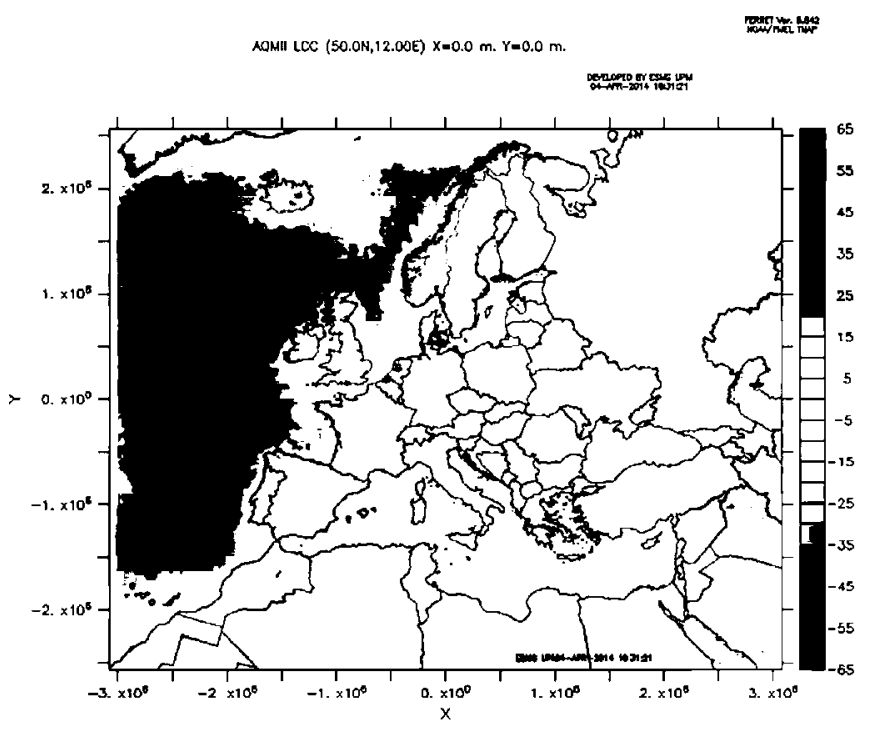

PBLH m FBES3_NONFBIT1 2010 AVG

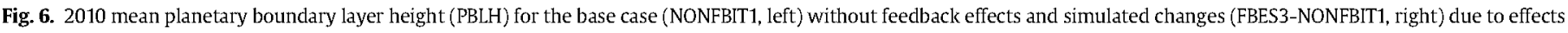
of aerosols.

Hourly values of simulated meteorology and species concentrations are evaluated using available observational data. Performance evaluation includes the following statistical parameters: Normalized Mean Bias (NMB), Normalized Mean Standard Error (NMSE), Root Mean Square Error (RMSE) and Pearson Correlation Coefficient (PCC). The model performance is evaluated for the two simulations, NONFBIT1 (base) and FBES3 (feedback effects). The simulation domain has been split into three parts: Northern Europe (NE) from latitude $51^{\circ} \mathrm{N}$, Central Europe (CE) for latitudes between $44^{\circ} \mathrm{N}$ and $54^{\circ} \mathrm{N}$ and finally Southern Europe (SE) for latitudes bellow $44^{\circ} \mathrm{N}$. Spatial average is applied for station and model values over the subdomain or for the full domain (ALL).

Table 1 shows domain average performance statistics over the
European domain (ALL), Northern Europe (NE), Central Europe (CE) and Southern Europe (SE).

The domain-wide performance statistics for variables predicted by NONFBIT1 and FBES3 are overall similar, noticeable changes occur for particles, due to different dust model implementations. Indeed, NONFBSIT1 included a modified Shaw et al. (2008) dust module for correcting the size distribution into MOSAIC aerosols with 4 bins. Moreover, a new dust flux constant and a desert dust improvement for spurious fluxes was introduced in the baseline simulation. $\mathrm{NO}_{2}, \mathrm{SO}_{2}$ are largely under predicted by both simulations with a NMB of more than $60 \%$. The underestimation can be attributed to overestimated surface wind speeds and/or underestimations of emissions. Wind speed (WSPD) is overpredicted 
Vertical profile FBES3-NONEBIT1

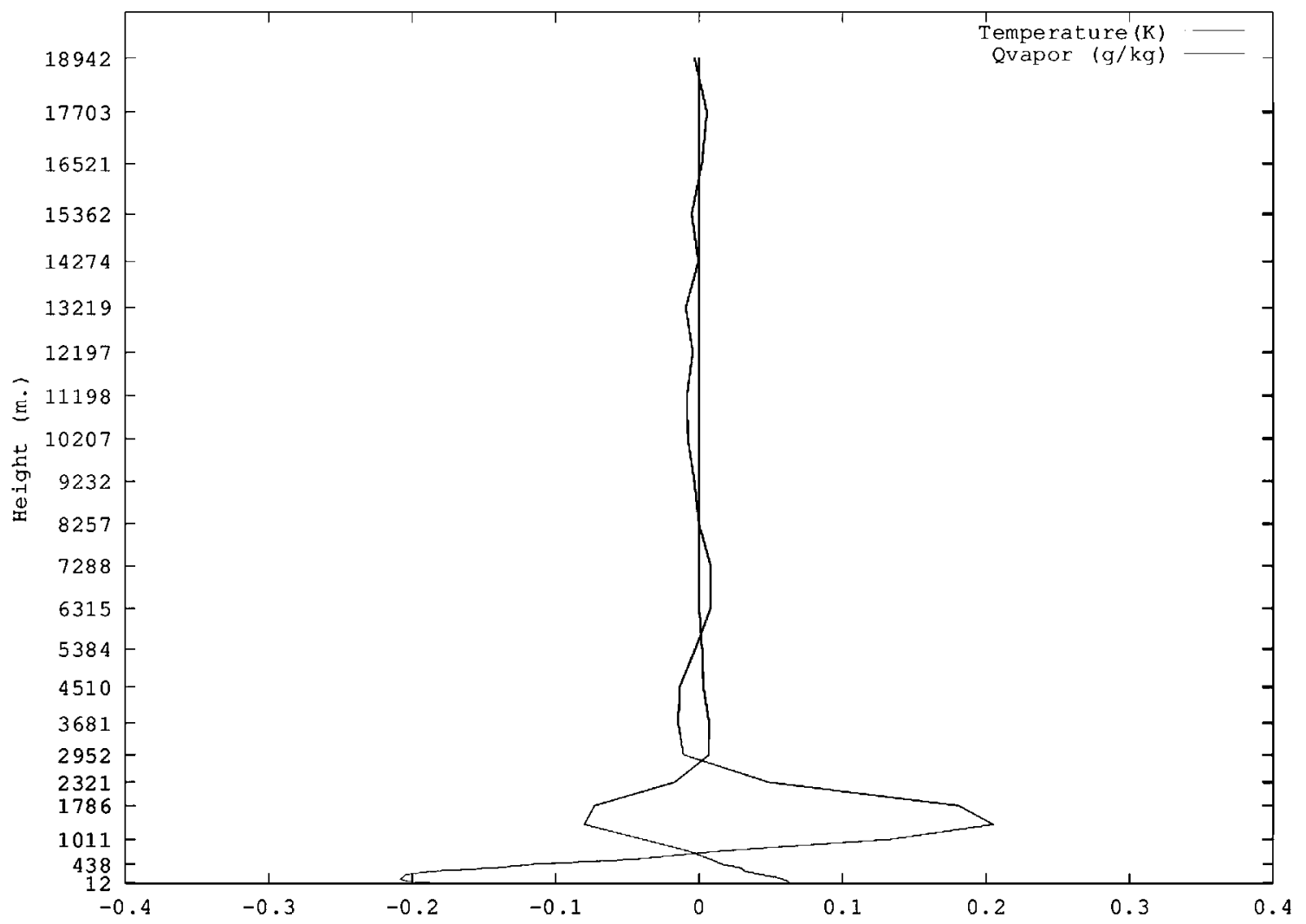

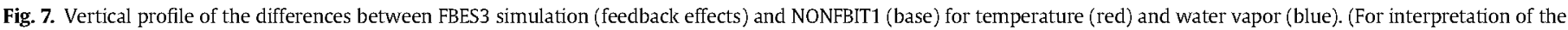
references to color in this figure legend, the reader is referred to the web version of this article.)
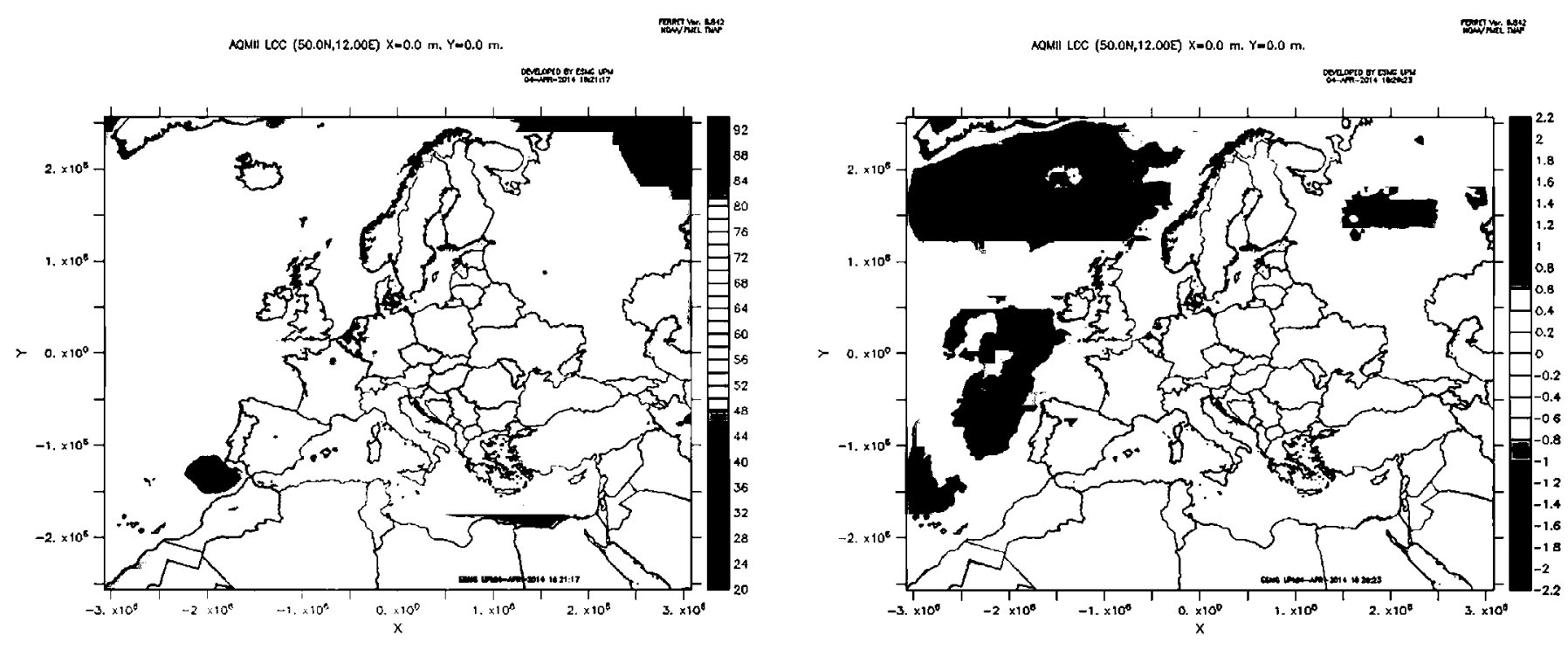

$03 \mathrm{ug} / \mathrm{m} 3$ NONFB.IT1 2010 AVG

$03 \mathrm{ug} / \mathrm{m} 3$ FBES3_NONFBIT1 2010 AVG

Fig. 8. 2010 mean ozone for base case (NONFBIT1, left) without feedback and simulated changes (FBES3-NONFBIT1, right) due to effects of aerosols.

for $35.5 \%$ (FBES3) and $34.7 \%$ (NONFBIT1). The high WSPD bias is mainly attributed to a poor representation of surface drag exerted by the unresolved topography. The simulated ozone and temperature agree reasonably well with observations at both simulations. The NONFBIT1 is slightly improved for ozone but is slightly worse for others from NMBs point of view. The correlation coefficient is slightly improved for the majority of the variables, demonstrating the benefits of using feedback effects for the temporal variability. The Central Europe subdomain gets better results for the majority of the variables. 


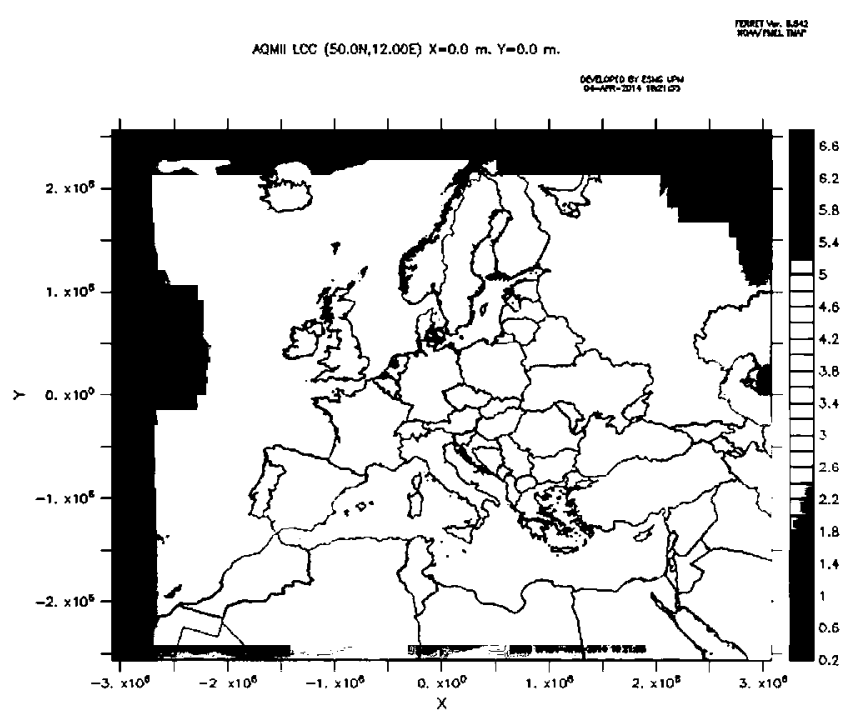

SO4 ug/m3 NONFB.IT1 2010 AVG

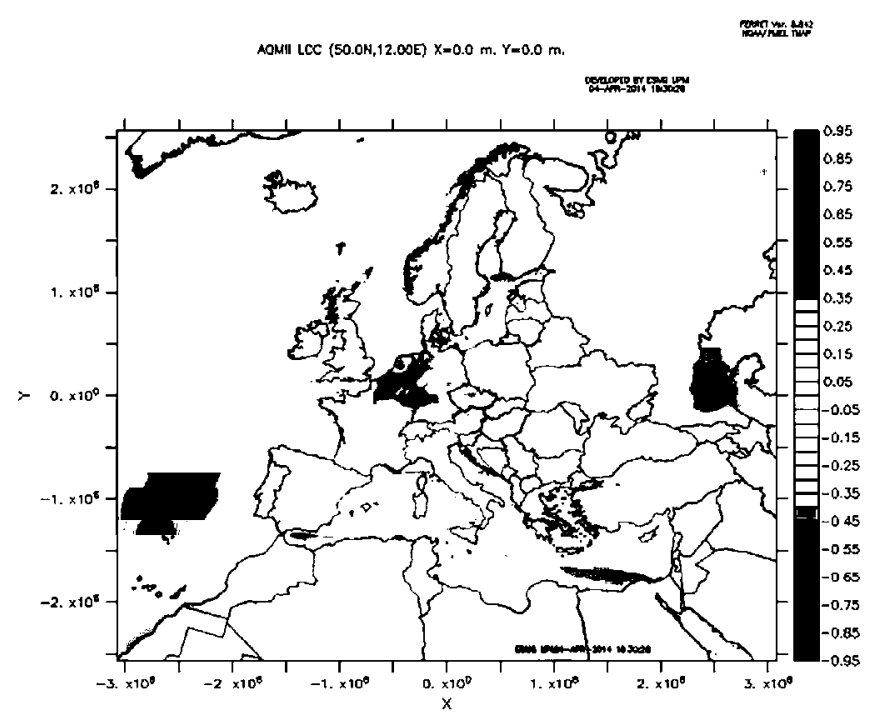

SO4 ug/m3 FBES3_NONFBIT1 2010 AVG

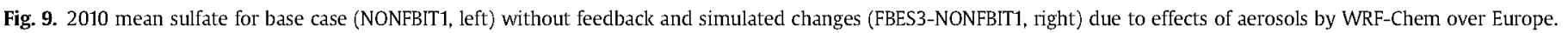

Table 1

Comparison of performance statistics of FBES3 and NONFBIT1 in 2010.

\begin{tabular}{|c|c|c|c|c|c|c|c|c|c|}
\hline \multirow[t]{2}{*}{ Variable } & \multirow[t]{2}{*}{ SIMULAT. } & \multicolumn{4}{|l|}{ NMB } & \multicolumn{4}{|l|}{ NMSE } \\
\hline & & $\mathrm{NE}$ & $\mathrm{CE}$ & SE & ALL & NE & $\mathrm{CE}$ & $\mathrm{SE}$ & ALL \\
\hline \multirow[t]{2}{*}{$\mathrm{NO} 2$} & FBES3 & $-0,743$ & $-0,622$ & $-0,702$ & $-0,625$ & 2760 & 1265 & 1971 & 1279 \\
\hline & NONFBIT1 & $-0,732$ & $-0,602$ & $-0,688$ & $-0,604$ & 2580 & 1132 & 1808 & 1132 \\
\hline \multirow[t]{2}{*}{$\mathrm{SO} 2$} & FBES3 & $-0,589$ & $-0,680$ & $-0,730$ & $-0,642$ & 1412 & 1878 & 2841 & 1508 \\
\hline & NONFBIT1 & $-0,571$ & $-0,642$ & $-0,724$ & $-0,618$ & 1324 & 1566 & 2796 & 1359 \\
\hline \multirow[t]{2}{*}{$\mathrm{O} 3$} & FBES3 & $-0,098$ & $-0,031$ & 0,032 & $-0,020$ & 0,058 & 0,053 & 0,024 & 0,038 \\
\hline & NONFBIT1 & $-0,093$ & $-0,033$ & 0,030 & $-0,021$ & 0,058 & 0,055 & 0,025 & 0,040 \\
\hline \multirow[t]{2}{*}{ PM10 } & FBES3 & $-0,522$ & $-0,573$ & $-0,751$ & $-0,587$ & 0,924 & 1327 & 2848 & 1188 \\
\hline & NONFBIT 1 & $-0,233$ & $-0,368$ & $-0,591$ & $-0,377$ & 0,271 & 0,537 & 1178 & 0,422 \\
\hline \multirow[t]{2}{*}{ PM25 } & FBES3 & $-0,351$ & $-0,455$ & $-0,070$ & $-0,423$ & 0,585 & 0,959 & 0,147 & 0,714 \\
\hline & NONFBIT1 & 0,003 & $-0,298$ & 0,200 & $-0,216$ & 0,260 & 0,507 & 0,145 & 0,304 \\
\hline \multirow[t]{2}{*}{ TEMP } & FBES3 & $-0,001$ & $-0,003$ & $-0,004$ & $-0,002$ & 0,000 & 0,000 & 0,000 & 0,000 \\
\hline & NONFBIT1 & $-0,001$ & $-0,003$ & $-0,004$ & $-0,002$ & 0,000 & 0,000 & 0,000 & 0,000 \\
\hline \multirow[t]{2}{*}{ WSPD } & FBES3 & 0,374 & 0,339 & 0,378 & 0,355 & 0,129 & 0,115 & 0,136 & 0,114 \\
\hline & NONFBIT1 & 0,371 & 0,329 & 0,369 & 0,347 & 0,129 & 0,114 & 0,134 & 0,112 \\
\hline \multirow[t]{2}{*}{ Variable } & SIMULAT. & \multicolumn{4}{|l|}{ RMSE } & \multicolumn{4}{|l|}{$\mathrm{PCC}$} \\
\hline & & $\mathrm{NE}$ & $C E$ & SE & ALL & $\mathrm{NE}$ & $\mathrm{CE}$ & SE & ALL \\
\hline \multirow[t]{2}{*}{$\mathrm{NO} 2$} & FBES3 & 14,459 & 15,233 & 14,522 & 14,686 & 0,719 & 0,844 & 0,782 & 0,829 \\
\hline & NONFBIT 1 & 14,281 & 14,792 & 14,222 & 14,238 & 0,717 & 0,842 & 0,788 & 0,824 \\
\hline \multirow[t]{2}{*}{$\mathrm{SO} 2$} & FBES3 & 2463 & 3615 & 6168 & 3900 & 0,693 & 0,804 & 0,218 & 0,744 \\
\hline & NONFBIT1 & 2436 & 3486 & 6182 & 3821 & 0,699 & 0,814 & 0,057 & 0,730 \\
\hline \multirow[t]{2}{*}{$\mathrm{O} 3$} & FBES3 & 12,104 & 11,237 & 9414 & 10,172 & 0,645 & 0,869 & 0,885 & 0,873 \\
\hline & NONFBIT1 & 12,066 & 11,499 & 9655 & 10,421 & 0,626 & 0,862 & 0,877 & 0,866 \\
\hline \multirow[t]{2}{*}{ PM10 } & FBES3 & 11,565 & 18,542 & 36,284 & 17,692 & 0,263 & 0,382 & 0,051 & 0,273 \\
\hline & NONFBIT1 & 7930 & 14,317 & 29,918 & 12,932 & 0,396 & 0,581 & 0,274 & 0,507 \\
\hline \multirow[t]{2}{*}{ PM25 } & FBES3 & 6134 & 13,149 & 3373 & 10,141 & 0,270 & 0,376 & 0,452 & 0,309 \\
\hline & NONFBIT1 & 5,075 & 10,816 & 3813 & 7689 & 0,334 & 0,595 & 0,450 & 0,519 \\
\hline \multirow[t]{2}{*}{ TEMP } & FBES3 & 1606 & 1454 & 1484 & 1325 & 0,986 & 0,988 & 0,988 & 0,991 \\
\hline & NONFBIT1 & 1675 & 1298 & 1447 & 1266 & 0,986 & 0,992 & 0,991 & 0,993 \\
\hline \multirow[t]{2}{*}{ WSPD } & FBES3 & 1443 & 1356 & 1512 & 1351 & 0,769 & 0,876 & 0,789 & 0,830 \\
\hline & NONFBIT1 & 1,444 & 1,329 & 1494 & 1337 & 0,764 & 0,874 & 0,777 & 0,821 \\
\hline
\end{tabular}

\section{Conclusions}

To investigate the sensitivity of the aerosol effects (direct plus indirect feedback effects) on meteorological variables and pollutant concentrations WRF-Chem model is applied over Europe in 2010. Two yearly simulations have been performed. The two case studies consist of one simulation without feedback effects (base) and the second one with direct aerosol effect, aerosol cloud interactions and indirect effects turned on. The yearly simulation permits to characterize the long-term variation trend. WRF-Chem variables are evaluated using available hourly observations in terms of performance statistics. Standardized observations from the ENSEMBLE system web-interface have been used. The research has been developed under the second phase of Air Quality Model Evaluation International Initiative (AQMEII).

Simulated feedback effects between aerosol concentrations and 
meteorological variables and on pollutant distributions strongly depend on the aerosol concentrations and the clouds. The analysis of the correlations between simulation and observations indicates slightly better results for the FBES3 simulation (with feedback effects). The performance of the WRF-Chem model can be considered to be reasonably good in terms of its overall capability of reproducing observed meteorological variables and chemical concentrations, although due to the coarse horizontal grid resolution and topography used in this study, wind speeds overestimation has been found.

As expected, the feedback effects are sometimes only minor effects, but a first analysis confirms that the sensitivity of the meteorology and air pollution to the aerosol concentrations can also be very important under certain circumstances. Although too low aerosol particle concentrations were simulated the results demonstrate the relevance of aerosol effects. A strong underestimation of the aerosol concentrations was not only found for WRFChem but also for the majority of the models participating in the AQMEII phase2. Further investigations are necessary with higher aerosol particle concentrations.

The most important effects were found for the North Atlantic zone with very low aerosol concentrations, low cloud droplet numbers and a reduced cloud liquid water path. For the WRF-Chem version applied here, the simulation without feedback effects uses constant and horizontally uniform droplet number concentrations, so the chosen number is a critical point when you have a single moment microphysics scheme (running without considering variable simulated aerosol concentrations). The inclusion of the feedback effects results in an increase of solar radiation by up to $70 \%$ over cloudy areas (North) due to the indirect aerosol effect and decrease up to $10 \%$ over more sunny locations (South) via backscattering. Aerosol effects produce an increase of the water vapor (up to 3\%) and precipitation and decrease the planet boundary layer height (up to 20\%) over the full domain except in the Sahara area where the maximum particle concentrations are detected. Ozone is increased (up to $3 \%$ ) over the Mediterranean area and decreased (up to $4 \%$ ) over the rest of the domain.

The two case studies presented here are complementary to further case studies with WRF-Chem within AQMEII. Forkel et al. (2015) and Baró et al. (2015) analized similar case studies where WRF-Chem was applied with a modal aerosol module and different gas phase chemistry, and with different cloud physics options. Comparison with the results presented there indicates the impact of using different cloud physics and chemistry modules on the model results and feedback effects are about of the same magnitude. However, when feedback effects were compared among simulations using the same configuration otherwise, the general impact of aerosol meteorology interactions shoed the same general features as presented here.

\section{Acknowledgment}

We gratefully acknowledge the contribution of various groups to the second air Quality Model Evaluation international Initiative (AQMEII) activity: TNO (anthropogenic emissions database); ECMWF/MACC project \& Météo-France/CNRM-GAME (chemical boundary conditions), FMI (fire emissions). Joint Research Center Ispra/Institute for Environment and Sustainability provided its ENSEMBLE system for model output harmonization and analyses, and evaluation. The UPM authors acknowledge the computer resources and technical assistance provided by the Centro de Supercomputación y Visualización de Madrid (CeSViMa). The UPM authors thankfully acknowledge the computer resources, technical expertise and assistance provided by the Red Española de Supercomputación. G. Curci and P. Tuccella were supported by the Italian
Space Agency (ASI), in the frame of the PRIMES project (contract $\mathbf{n}$. I/017/11/0).

\section{References}

Andreae, M.O., Merlet, P., 2001. Emission of trace gases and aerosols from biomass burning. Glob. Biogeochem. Cycles 15 (4), 955-966.

Baklanov, A., Schlünzen, K.H., Suppan, P., Baldasano, J., Brunner, D., Aksoyoglu, S., Carmichael, G., Douros, J., Flemming, J., Forkel, R., Galmarini, S., Gauss, M., Grell, G., Hirtl, M., Joffre, S., Jorba, O., Kaas, E., Kaasik, M., Kallos, G., Kong, X. Korsholm, U., Kurganskiy, A., Kushta, J., Lohmann, U., Mahura, A., MandersGroot, A., Maurizi, A., Moussiopoulos, N., Rao, S.T., Sokhi, R.S., Savage, N., Seigneur, C., Solomos, S., Sørensen, B., Tsegas, G., Vignati, E., Vogel, B., Zhang, Y. 2014. Online coupled regional meteorology-chemistry models in Europe: current status and prospects. Atmos. Chem. Phys. 14, 317-398.

Bangert, M., Nenes, A., Vogel, B., Vogel, H., Barahona, D., Karydis, V.A., Kumar, P., Kottmeier, C. Blahak, U., 2012. Saharan dust event impacts on cloud formation and radiation over Western Europe. Atmos. Chem. Phys. 12, 4045-4063. http:// dx.doi.org/10.5194/acp-12-4045-2012.

Bessagnet, B., Menut, L., Curci, G., Hodzic, A., Guillaume, B., Liousse, C., Moukhtar, S. Pun, B., Seigneur, C., Schulz, M., 2008. Regional modeling of carbonaceous aerosols over Europe-Focus on secondary organic aerosols. J. Atmos. Chem. 61, $175-202$.

Bianconi, R., Galmarini, S., Bellasio, R., 2004. Web-based system for decision support in case of emergency: ensemble modelling of long-range atmospheric dispersion of radionuclides. Environ. Model. Softw. 19, 401-411.

Builtjes, P. J. H.: Aerosols over Europe, Focus on Black carbon, TNO report R2003/ 146, February 2003.

Chapman, E.G., Gustafson Jr., W.I., Easter, R.C., Barnard, J.C., Ghan, S.J., Pekour, M.S., Fast, J.D., 2009. Coupling aerosol-cloud-radiative processes in the WRF-Chem model: investigating the radiative impact of elevated point sources. Atmos. Chem. Phys. 9, 945-964.

Chen, F., Dudhia, J., 2001. Coupling an advanced land surface-hydrology model with the Penn State-NCAR MM5 modeling system. Part I: model implementation and sensitivity. Mon. Weather Rev. 129, 569-585.

Chen, S., Zhao, C., Qian, Y., Leung, L.R., Huang, J., Huang, Z., Bi, J., Zhang, W., Shi, J., Yang, L., Li, D., Li, J., 2014. Regional modeling of dust mass balance and radiative forcing over East Asia using WRF-Chem. Aeolian Res. http://dx.doi.org/10.1016/ j.aeolia.2014.02.001.

Emmons, L.K., Walters, S., Hess, P.G., Lamarque, J.-F., Pfister, G.G., Fillmore1, D., Granier, C., Guenther, A., Kinnison, D., Laepple, T., Orlando, J., Tie, X., Tyndall, G., Wiedinmyer, C., Baughcum, S.L., Kloster, S., 2010. Description and evaluation of the Model for Ozone and Related chemical Tracers, version 4 (MOZART-4). Geosci. Model Dev. 3, 43-67.

Fast, J.D. Gustafson Jr., W.I., Easter, R.C. Zaveri, R.A. Barnard, JC., Chapman, E.G. Grell, G.A., Peckham, S.E., 2006. Evolution of ozone, particulates, and aerosol direct radiative forcing in the vicinity of Houston using a fully coupled meteorology-chemistry-aerosol model. J. Geophys. Res. 111, D21305. http:// dx.doi.org/10.1029/2005/D006721.

Forkel, R., Werhahn, J., Buus Hansen, A., McKeen, S., Peckham, S., Grell, G., Suppan, P., 2012. Effect of aerosol-radiation feedback on regional air quality e a case study with WFR/Chem. Atmos. Environ. 53, 202-211.

Forkel, R., Balzarini, A., Baró, R., Curci, G., Jiménez-Guerrero, P., Hirtl, M., Honzak, L. Im, U., Lorenz, C., Pérez, J.L., Pirovano, G., San José, R., Tuccella, P., Werhahn, J., Zabkar, R., 2015. Analysis of the WRF-Chem contributions to AQMEIl phase2 with respect to aerosol radiative feedbacks on meteorology and pollutant distribution. Atmos. Environ. 115, 630-645.

Galmarini, S., Bianconi, R., Appel, W., Solazzo, E., Mosca, S., Grossi, P., Moran, M., Schere, K., Rao, S.T., 2012. ENSEMBLE and AMET: two systems and approaches to a harmonised, simplified and efficient assistance to air quality model developments and evaluation. Atmos. Environ. 53, 51-59.

Grell, G., Baklanov, A., 2011. Integrated modeling for forecasting weather and air quality: a call for fully coupled approaches. Atmos. Environ. 45, 6845-6851.

Grell, G.A., Devenyi, D., 2002. A generalized approach to parameterizing convection combining ensemble and data assimilation techniques. Geophys. Res. Lett. 29 (14). Article 1693

Grell, G.A., Peckham, S.E., Schmitz, R., McKeen, S.A., Frost, G., Skamarock, W.C., Eder, B., 2005. Fully coupled 'online' chemistry in the WRF model. Atmos. Environ. 39, 6957-6976.

Grell, G.A., Freitas, S.R., Stuefer, M., Fast, J., 2011. Inclusion of biomass burning in WRF-Chem: impact of wildfires on weather forecasts. Atmos. Chem. Phys. 11, 5289-5303.

Guenther, A., Karl, T., Harley, P., Wiedinmyer, C, Palmer, PI, Geron, C, 2006. Estimates of global terrestrial isoprene emissions using MEGAN (Model of Emissions of Gases and Aerosols from Nature). Atmos. Chem. Phys. 6, 3181-3210.

Haywood, J., Ramaswamy, V., Soden, B., 1999. Tropospheric aerosol climate forcing in clear-sky satellite observations over the oceans. Science 283, 1299-1303.

Hong, S., Noh, Y., Dudhia, J., 2006. A new vertical diffusion package with an explicit treatment of entrainment processes. Mon. Weather Rev. 134, 2318-2341.

Iacono, M.J., Delamere, J.S., Mlawer, E.J., Shephard, M.W., Clough, S.A., Collins, W.D., 2008. Radiative forcing by long-lived greenhouse gases: calculations with the AER radiative transfer models. J. Geophys. Res. 113, D13103.

Jacob, D.J., Winner, D.A., 2009. Effect of climate change on air quality. Atmos. 
Environ. 43, 51-63.

Johnson, B.T., Osborne, S.R., 2011. Physical and optical properties of mineral dust aerosol measured by aircraft during the GERBILS campaign. Q. J. R. Meteorol. Soc. 137 (658), 1117-1130.

Kaufman, Y.J., Fraser, R.S., 1997. The effect of smoke particles on clouds and climate forcing. Sci. Wash. D.C. 277 (5332), 1636-1638.

Kong, X., Forkel, R., Sokhi, R.S., Suppan, P., Baklanov, A., Gauss, M., Brunner, D., Baro, R., Balzarini, A., Chemel, C., Curci, G., Guerrero, P.J., Hirtl, M., Honzak, L., Im, U., Perez, J.L., Pirovano, G., San Jose, R., Schlünzen, K.H., Tsegas, G., Tuccella, P., Werhahn, J., Zabkar, R., Galmarini, S., 2015. Analysis of meteorology chemistry interactions during air pollution episodes using online coupled models within AQMEII phase-2. Atmos. Environ. 115, 527-540.

Konovalov, I.B., Beekmann, M., Kuznetsova, I.N., Yurova, A., Zvyagintsev, A.M., 2011. Atmospheric impacts of the 2010 Russian wildfires: integrating modelling and measurements of an extreme air pollution episode in the Moscow region. Atmos. Chem. Phys. 11, 10031-10056. http://dx.doi.org/10.5194/acp-11-100312011.

Kuenen, J.J.P., Visschedijk, A.J.H., Jozwicka, M., Denier van der Gon, H.A.C., 2009. TNO-MACC_II emission inventory: a multi-year (2003-2009) consistent highresolution European emission inventory for air quality modeling. Atmos. Chem. Phys. Discuss. 14, 5837-5869. http://dx.doi.org/10.5194/acpd-14-58372014.

Levin, Z., Brenguier, J.-L., 2009. Effects of pollution and biomass aerosols on clouds and precipitation: observational studies (Chapter 6). In: Levin, Z., Cotton, W.R. (Eds.), Aerosol Pollution Impact on Precipitation: a Scientific Review. Springer. ISBN 978-1-4020-8689-2.

Morrison, H., Thompson, G., Tatarskii, V., 2009. Impact of cloud microphysics on the development of trailing stratiform precipitation in a simulated squall line: comparison of one and two-moment schemes. Mon. Weather Rev. 137, 991-1006.

Rosenfeld, D., Woodley, W.L., 1999. Satellite-inferred impact of aerosols on the microstructure of Thai convective clouds. In: Proceedings, Seven WMO Scientific Conference on Weather Modification, Chiang Mai, Thailand, 17e22 February $1999,17 \mathrm{e} 20$.

Shaw, W.J., Allwine, K., Fritz, B.G., Rutz, F.C., Rishel, J.P., Chapman, E.G., 2008. An evaluation of the wind erosion module in DUSTRAN. Atmos. Environ. 42, 1907-1921. http://dx.doi.org/10.1016/j.atmosenv.2007.11.022.
Sofiev, M., Vankevich, R., Lotjonen, M., Prank, M., Petukhov, V., Ermakova, T., Koskinen, J. Kukkonen, J, 2009. An operational system for the assimilation of the satellite information on wild-land fires for the needs of air quality modelling and forecasting. Atmos. Chem. Phys. 9, 6833-6847. http://dx.doi.org/ 10.5194/acp-9-6833-2009.

Tuccella, P., Curci, G., Visconti, G., Bessagnet, B., Menut, L., Park, R.J., 2012. Modeling of gas and aerosol with WRF-Chem over Europe: evaluation and sensitivity study. J. Geophys. Res. 117.

Wiedinmyer, C., Akagi, S.K., Yokelson, R.J., Emmons, L.K., Al-Saadi, J.A., Orlando, J.J Soja, A.J., 2011. The Fire INventory from NCAR (FINN): a high resolution global model to estimate the emissions from open burning. Geosci. Model Dev. 4, 625-641. http://dx.doi.org/10.5194/gmd-4-625-2011.

Wild, O., Zhu, X., Prather, M.J., 2000. Fast-J: accurate simulation of in-and below cloud photolysis in tropospheric chemical models. J. Atmos. Chem. 37, 245-282.

Wolke, R., Schröder, W., Schrödner, R., Renner, E., 2012. Influence of grid resolution and meteorological forcing on simulated European air quality: a sensitivity study with the modeling system COSMO-MUSCAT. Atmos. Environ. 53, 110-130. http://dx.doi.org/10.1016/j.atmosenv.2012.02.085.

Wong, D.C., Pleim, J., Mathur, R., Binkowski, F., Otte, T., Gilliam, R., Pouliot, G., Xiu, A Young, J.O., Kang, D., 2012. WRF-CMAQ two-way coupled system with aerosol feedback: software development and preliminary results. Geosci. Model Dev. 5, 299-312. http://dx.doi.org/10.5194/gmd-5-299-2012.

Yang, Q., Gustafson Jr., WI., Fast, J.D Wang H., Easter, RC., Morrison, H., 2011. Assessing 699 regional scale predictions of aerosols, marine stratocumulus, and their interactions during 700 VOCALS-REx using WRF-Chem. Atmos. Chem. Phys. 11, 11951-11975. http://dx.doi.org/10.5194/acpd-11-22663-2011.

Zaveri, R.A., Peters, L.K., 1999. A new lumped structure photochemical mechanism for largescale applications. J. Geophys. Res. 104, 30387-30415.

Zaveri, R.A., Easter, R.C., Fast, J.D., Peters, L.K., 2008. Model for simulating aerosol interactions and chemistry (MOSAIC). J. Geophys. Res. 113, D13204. http:// dx.doi.org/10.1029/2007JD008782.

Zhang, Y., 2008. Online-coupled meteorology and chemistry models: history, current status, and outlook. Atmos. Chem. Phys. 8, 2895-2932.

Zhang, Y., Wen, X.-Y., Jang, C.J., 2010. Simulating chemistry-aerosol-cloud-radiationclimate feedbacks over the continental US using the online-coupled Weather Research Forecasting Model with chemistry (WRFChem). Atmos. Environ. 44, 3568-3582. http://dx.doi.org/10.1016/j.atmosenv.2010.05.056. 